Akiko Shibui - Takeshi Tsunoda • Naohiko Seki

Yutaka Suzuki • Kazuo Sugane • Sumio Sugano

\title{
Isolation and chromosomal mapping of a novel human gene showing homology to $\mathrm{Na}^{+} / \mathrm{PO}$ cotransporter
}

Received: December 4, 1998 / Accepted: January 20, 1999

\begin{abstract}
We isolated a cDNA clone which shows a significant similarity with the renal $\mathrm{Na}^{+} /$phosphate cotransporter (NPT) from a human intestine mucosa cDNA library. The cDNA is 2626 bases long, with one open reading frame encoding a protein of 497 amino acids. The deduced amino acids sequence shows an overall homology of $48 \%$ with the human renal NPT1 protein. This gene is expressed in intestine, colon, liver, and pancreas. Thus, this gene may code for intestinal type NPT or closely related proteins. The chromosomal location of the gene was determined on the chromosome 6p21.3-p22 region by polymerase chain reaction-based analysis with both a human/rodent mono-chromosomal hybrid cell panel and a radiation hybrid mapping panel.
\end{abstract}

Key words $\mathrm{Na}^{+} /$Phosphate cotransporter (NPT) - Intestine Chromosome 6p21.3-p22 · RT-PCR · cDNA library

\section{Introduction}

Phosphate homeostasis in humans is maintained by the balance between intake, intestinal absorption, bone deposition and resorption, and renal excretion. The central molecule for the control of kidney excretion is the $\mathrm{Na}+$ /phosphate cotransporter (NPT), which is located in the proximal tubule (Biber 1989, Biber et al. 1993). This molecule uses the transmembrane electrochemical potential gradient of so-

A. Shibui $\cdot$ T. Tsunoda $\cdot$ Y. Suzuki $\cdot$ S. Sugano $(\triangle)$

Department of Virology, the Institute of Medical Science, the

University of Tokyo, Shirokane-dai, Minato-ku, Tokyo 108-8639, Japan

Tel. +81-3-5449-5286; Fax +81-3-5449-5416

e-mail: ssugano@ims.u-tokyo.ac.jp

A. Shibui $\cdot$ K. Sugane

Department of Parasitology, Sinshu University School of Medicine, Nagano, Japan

N. Seki

Genome Research Group, National Institute of Radiological Science, Chiba, Japan dium to transport phosphate across the cell membrane (Murer et al. 1991). A similar NPT also plays an important role in the absorption of the phosphate in the intestine mucosa (Murer et al. 1994). While human NPT of the kidney has been cloned (Chong et al. 1993) and studied, the molecular structure of human intestinal NPT is yet to be elucidated. Here, we report the isolation of a novel cDNA with significant homology to the renal NPT1 from the human intestinal mucosa cDNA library.

\section{Results and discussion}

A full length-enriched cDNA library was constructed, using the oligo-capping method (Maruyama and Sugano 1994, Suzuki et al. 1997) with mRNA isolated from normal mucosa of ileum. The sequences of the $5^{\prime}$ ends of the cDNA clones from the library were determined for 3150 clones. One clone, kaia2138, showed significant homology to human renal NPT1 cDNA. We determined the entire sequence of this clone. The nucleotide sequence data reported here will appear in the DDBJ, EMBL, and GenBank nucleotide sequence databases, with accession number AB020527. The cDNA was 2626 bp in length and has one open reading frame encoding a protein of 497 amino acids. A homology search revealed that it is homologous to the NPT family. Recently, human NPT3 and NPT4 cDNAs, homologous to human NPT1, were isolated from a 1.1-megabase region of the hereditary hemochromatosis locus of human chromosome 6. Their nucleotide sequences have been submitted to GenBank. The multiple alignments of amino acid sequences of the kaia2138 protein and NPTs are shown in Fig. 1. The kaia2138 protein was most homologous to the human NPT3 protein, having $54 \%$ identity at the amino acid level. The amino acid sequence of kaia2138 was $48 \%$ identical to human NPT1 and $43.5 \%$ identical to human NPT4.

The expression level of this gene was not detectable by Northern blot analysis, so we examined the tissue distribution of the transcript in various human adult tissues by reverse transcription-coupled polymerase chain reaction (RT-PCR). Primers used for RT-PCR were to amplify the 
Fig. 1. Multiple alignment of kaia2138 (accession number AB020527) and $\mathrm{Na}^{+} /$ phosphate cotransporter (NPT) families. The NPT sequences are human NPT1 (NPT1_HUMAN; accession number Q14916), rabbit NPT1 (NPT1_RABIT; accession number Q28722), rat NPT1 (NPT1_RAT; accession number Q62795), mouse NPT1 (NPT1_MOUSE; accession number Q61983), human NPT3 (NPT3 HUMAN; accession number O00624) and human NPT4 (NPT4_HUMAN; accession number O00476). Identities are indicated by shadowed background. Asterisks denote the terminal codon kaia2138 NPT1_HUMAN NPT1_RABIT NPT1_RAT NPT1_MOUSE NPT3 HUMAN NPT4_HUMAN

kaia2138 NPT1_HUMAN NPT1_RABIT NPT1_RAT NPT1_MOUSE NPT3 HUMAN NPT4_HUMAN

kaia2138 NPT1_HUMAN NPT1_RABIT NPT1_RAT NPT1_MOUSE NPT3_HUMAN NPT4_HUMAN

kaia2138 NPT1_HUMAN NPT1_RABIT NPT1_RAT NPT1_MOUSE NPT3_HUMAN NPT4_HUMAN

kaia2138 NPT1_HUMAN NPT1_RABIT NPT1_RAT NPT1_MOUSE NPT3_HUMAN NPT4_HUMAN

kaia2138 NPT1_HUMAN NPT1_RABIT NPT1_RAT NPT1_MOUSE NPT3_HUMAN NPT4_HUMAN

kaia2138 NPT1_HUMAN NPT1_RABIT NPT1_RAT NPT1_MOUSE NPT3_HUMAN NPT 4_HUMAN

kaia2138 NPT1_HUMAN NPT1_RABIT NPT1_RAT NPT1_MOUSE NPT 3 HUMAN NPT 4_HUMAN

kaia2138 NPT1_HUMAN NPT1 RABIT NPT1_RAT NPT1_MOUSE NPT3_HUMAN NPT4_HUMAN
1:MSTGPDVKATVGDISSDGNLNVAOEECSRKGFCSVRHGLALILOLCNF STYTOOMNLSIA 60 $1:----1,-M D N R$ PPKKVPGECSFRYGLSFLVHCCNVIITAQRACLNLT 4 $1:-\ldots-1$ $1: \cdots-M E N R C L P K V P G F C S F R Y G L A$ ILLHFCNIVIMAQRVCLNLT 41 $1:-1,-M E N Q C L P K K V P G F C S F R Y G L A I L L H F C N I A T M A Q R V C L N L T$ $1: \ldots-\ldots$ MDGKPATRKGPDFCSLRYGLALIMHF SNFTMITQRVSLSIA 41 $1:-----10$ MQVTLIPRKGPSLCSARYGIALVLHFCNFTTIAQNVIMNIT 43

61: IPAMVNNTAPPSOPNASTERPSTDSOGYWNETLKEFKAMAPAYTWSPEIOGIILSSLNYG 120 42 : MVVMVNSTDPHGLPNTS--------TKKLLDNIR--NPMYNWSPDIOGIILSSTSYG 88 42 : MVAMVNNTNLHGSPNTS-----_--AEKRLDNTK--NPVYNWSPDVQGIIFSSIFYG 88 42 : MVAMVNKTEPPHLSNKS---------VAEMLDNVK--NPVHSWSLDIQGLVLSSVFLG 88 42 : MVAMVNNTGSPHLSNES----------VVBMLDNVK--NPVYSWSPDIQGLILSSVFFG 88 42 : IIAMVNTTQQQGLSNASTEGPVADAFNNSSISIKEFDTKASVYQWSPETQGI IFSSINYG 101 44 : MVAMVNSTSPQSQLNDSSE--- 62

121 : SFLAPIPSGYVAGIFGAKYVVGAGLFISSFLTLFIPLAANAGVALLIVLRIVOGIAOVMV 180 89: VIIIOVPVGYFSGIYSTKKMIGFALCLSSVLSLILIPPAAGIGVAWVVVCRAVOGAAOGIV 148 89: AFLIQIPVGYISGIYSIKKLIGFALFLSSLVS IFIPQAAAVGETWIIVCRVVQGITQGTV 148 89 : MVVIQVPVGYLSGAYPMEKIIGSSLFLSSVLSLLIPPAAQVGAALVIVCRVLQGIAQGAV 148 89 : MVVVQAPVGYLSGIYPMKRI IGSSLFLSSLMSLLIPPAAQVGAALVIVCRVLQGIAQGTV 148 102 : IILTLIPSGYLAGIFGAKKMLGAGLLISSLLTLFTPLAADFGVILVIMVRTVOGMAOGMA 161 $63:---$ VLPVDSFGGLSKAPKSL----

181 : LTGOYSIWVKWAPPLERSOLTTIAGSGSMLGSFIVLLAGGLLCOTIGWPYVFYIFGGIGC 240 149 : ATAOFEIYVKWAPPLERGRLTSMSTSGFLLGPFIVLLVTGVICESLGWPMVFYIFGACGC 208 149 : TTAQHEIWVKWAPPLERGRLTSMSLSGFLLGPF IVLLVTGI ICESLGWPMVFY IFGACGC 208 149 : STGQHGIWVKWAPPLERGRLTSMTLSGFVMGPFIALLVSGF ICDLLGWPMVFY IFGIVGC 208 149 : STGQHEIWVKWAPPLERGRLTSMTLSGFVMGPFIVLLVSGF ICDLLGWPMVFYIFGIVGC 208 162 : WTGQFTIWVKWAPPLERSKLTTIAGSGSAFGSFIILCVGGL I SOALSWPFIFYIFGSTGC 221 86 : LGGQFAIWEKWGPPQERSRLCSIALSGMLLGCFTAILIGGF ISETLGWPFVFY IFGGVGC 145

241 : ACCPLWF PLIYDDPVNHPFISAGEKRYIVCSLAOODCSPGWSLPIRAMIKSLPLWAILVS 300 209 : AVCLLWFVLFYDDPKDHPCISI SEKEYITSSLVOOVSSSROSLPIKÄILKSLPVWATSIG 268 209 : AVCLLWFVLYYDDPKDHPCVSLHEKEYITSSLIQQGSSTRQSLPIKAMI KSLPLWAISFC 268 209 : VLSLFWE I LLFDDPNNHPYMSSSEKDYIT SSLMQQVHSGRQSLPIKAMLKSLPLWAIILN 268 209 : VLSLSWFFLFFDDPKDHPYMSSSEKDYIISSLMQQASSGRQSLPIKAMLKSL PLWAIILN 268 222 : VCCLLWFTVIYDDPMHHPCISVREKEHILSSLAQQPSSPGRAVPIKAMVTCLPLWAIFLG 281 146 : VCCLLWFVVIYDDPFSYPWISTSEKEYIISSLKOOVGSSKOPLPIKAMLRSLPIWSICLG 205

301 : YFCEYWLFYTIMAYTPTY ISSVLQANLRDSGILSALPFVVGCICIILGGLLADFLLSRKI 360 269 : SFTFFWSHNIMTLYTPMETNSMTHVNIKENGFLSSLPYLFAWTCGNLAGOLSDFFLTRNI 328 269 : CFAYLWTYSRLIVYTPTLINSMLHVDIRENGLLSSLPYLFAWICGVIAGHTADFLMSRNM 328 269 : SFAFI WSNNLLVTYTPTFISTTLHVNVRENGLLSSLPYLLAYICGIVAGQMSDFLLSRKI 328 269 : SFAFIWSNSLLVTYTPTFISTVLHVNVRENGLLSSLPYLLAYICGILAGQMSDFFLTRKI 328 282 : FFSHFWLCTI ILTYLPTY ISTLLHVNIRDSGVLSSLPF IAAASCTILGGQLADFLLSRNL 341 206 : CFSHQẄLVSTMVVY I PTY ISSVYHVNIRDNGLLSALPE IVAWVIGMVGGYLADFLLTK-K 264

361 : LRLITIRKLFTAIGVLFPSVILVSLPWVRSSHSMTMTELVLSSAISSFCESGALVNFLDI 420 329. LSVTAVRKLFTAAGFLI PAIFGVCLPYLSSTFYSIVIFLITAGĀTGSFCLGGVFINGLDI 388 329 : LSLTAIRKLFTAIGLLLPIVF SMCLLYLSSGFY STITFLILANÄSSSFCLGGALINALDL 388 329 : FSVVAVRKLFTTLGIFCPVIFVVCLLYLSYNFY STVIFLTLANSTLSFSFCGQLINALDI 388 329 : FSIVTVRKLFTTLGSFCPVIFIMCLLYLSYNFYSTVIFLTLANSTLSFSYCGQLINALDI 388 342 : LRLITVRKLFSSLDMQVSSWE----SQ----------GDLGSSQESSLPLPLDSS 382 265 : FRLITVRKIATILGSLPSSALIVSLPYLNSGYITATALLTLSCGLSTLCQSGIYINVLDI 324

421 : APRYTGFLKGLLQVFAHIAGAISPTAAGFFISQDSEFGWRNVFLLSAAVNISGLVFYLIF 480 389 : APRYFGFIKACSTLTGMIGGL IASTLTGLILKODPESAWFKTFILMAAINVTGLIFYLIV 448 389 : APRYYVFIKGVTTLIGMTGGMTSSTVAGLFLSODPESSWFKIFLLMSIINVISVIFYLIF 448 389 : APRYYGFLKAVTALIGIFGGLISSTLAGLILNQDPEYAWNHKNFFLMAGINVTCLAFYLLF 448 389 : APRYYGFLKAVTALIGMFGGLISSTLAGLILNQDPEYAWHKI SFLMÄGINVTCLVFYFLF 448 383 : SVRILSLVGGMSF SCLLQSTCLAWSFTSRLDKQNFKTGPKRGPLPASEDIKLQT* -- - -- 436 325 : APRYSSFLMGASRGESSIAPVIVPTVSGELLSQDPEFGWRNVFFLLFAVNLLGLLFYLIR 384

481 : GRADVQDWAKEQTFTHL * 449 : ATAEIQDWAKEKQHTRL* * 449 : AKAEIODWAKEKOHTRL * 449 : AKGDIQDWAKETKTTRL * 449 : AKGEIQDWAKBIKTTRL*

385 : GEADVOEWAKERKLTRL*

.


Fig. 2. Reverse transcription-coupled polymerase chain reaction (RTPCR) analysis of kaia2138 in multiple human tissues. Primers used for RT-PCR amplify $407 \mathrm{bp}$ of the $3^{\prime}$-non-coding region of the cDNA. The primers were (5'-TACCTGTGCTCCAGAGTTAGC- $\left.3^{\prime}\right)$ and $\left(5^{\prime}\right.$ CTTATGATCCTCCATGC-TGC-3'). The cDNA templates for RTPCR were from the human tissues of poly (A)+ RNAs and purchased from Clontech (Palo Alto, CA, USA). PCR was carried out in a final volume of $50 \mu \mathrm{l}$ containing $1 \times$ GC buffer I (Takara, Kyoto, Japan), $0.2 \mu \mathrm{M}$ each primer, $400 \mu \mathrm{M}$ each dNTP, $5 \mu \mathrm{l}(\sim 1 \mathrm{ng})$ of template cDNA and 2.5 units of LA-Taq DNA polymerase (Takara, Kyoto, Japan). For the positive control, $50 \mathrm{pg}$ of the kaia2138 clone from a full-length enriched cDNA library was used for the template. The temperature and time schedules were: 35 cycles at $94^{\circ} \mathrm{C}$ for $1 \mathrm{~min}, 55^{\circ} \mathrm{C}$ for $1 \mathrm{~min}$, and $72^{\circ} \mathrm{C}$ for $1 \mathrm{~min}$. PCR products were separated on $2.0 \%$ agarose gel. The lower panel shows the result with a Human G3PDH Control Amplimer Set (Clontech). The control G3PDH cDNA was also purchased from Clontech and used for PCR $(5 \mu \mathrm{l}[\sim 1 \mathrm{ng}])$

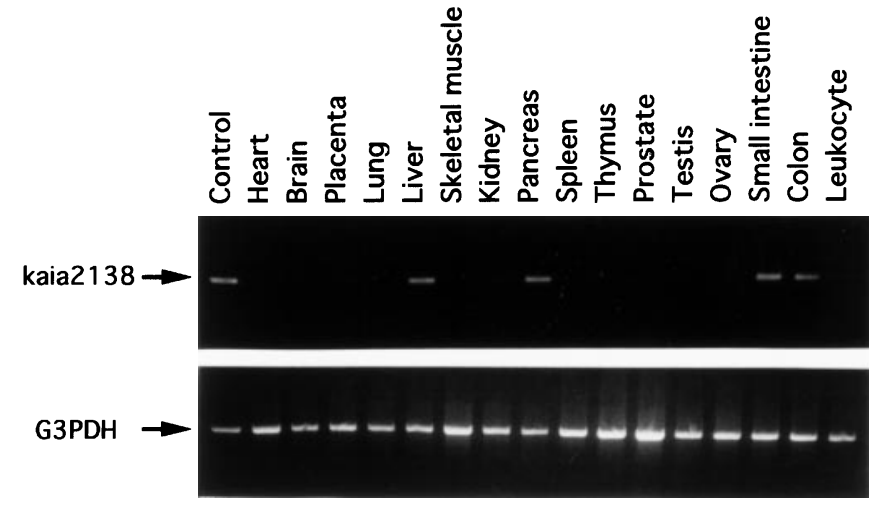

Fig. 3. Chromosomal placement of the kaia 2138 gene at a relative distance to framework markers on the WICGR (Whitehead Institute for Biomedical Research/ MIT Center for Genome Research) radiation hybrid map of the human genome (http://www.genome.wi.mit. edu/). The approximate corresponding cytogenetic location of the gene on the long arm of the telomeric (tel) region of human chromosome 6 is indicated. Distances of the markers are in centirays (cR) and centimorgans (cM) from the top of the chromosome 6 linkage group. Cen, Centromeric region
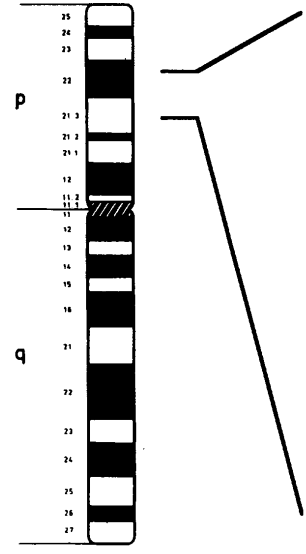

D6S461

WI-3998 (D6S1469)

D6S1554

CHLC.GATA89B07

Kaia2138

WI-4509 (D6S1294)

D6S464

D6S276

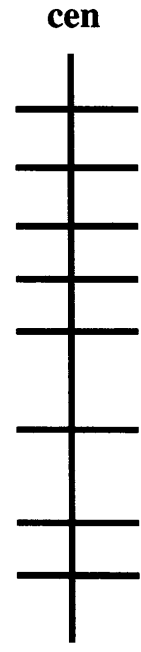

$(41.3 \mathrm{cM})$

$128.64 \mathrm{cR}$

$130.36 \mathrm{cR}(42.0 \mathrm{cM})$

$131.26 \mathrm{cR}$

132.27 cR

$136.71 \mathrm{cR}$

(44.3 cM)

$(44.9 \mathrm{cM})$

tel

\section{Chromosome 6}

amplified product for humans was detected only from the hybrid containing human chromosome 6 (data not shown). Then, we performed further mapping analysis using a PCRbased radiation hybrid panel (Genebridge 4; Research Genetics) with the same primers as those used in the assay for the human/rodent somatic cell hybrid panel. Statistical analysis of the radiation hybrid data was performed using the RHMAPPER software package (http://wwwgenome.wi.mit.edu/cgi-bin/contig/rhmapper.pl). The data vector for the gene was 100000010000100000001100000000 10010101001110010000000100000101100000100011001100 1111010000001 and the consequent report indicated that the gene was placed to $1.01 \mathrm{cR}$ proximal from CHLC.GATA89B07 (lod>3.0), which was cytogenetically mapped to the 6p21.3-p22 region (Fig. 3). The human renal NPT1 gene was also mapped to 6p21.3-p23 (Chong et al. 1993). Furthermore, NPT3 and NPT4 were identified within a 1.1-megabase region of the hereditary hemochromatosis locus (Lauer et al. 1997), which is located at 6p21.3p22. It is possible that human NPT genes are clustered around the chromosome $6 \mathrm{p} 21-\mathrm{p} 23$ region.

\section{References}

Biber J (1989) Cellular aspects of proximal tubular phosphate reabsorption. Kidney Int 36: 360-369

Biber J, Custer M, Werner A, Kaissling B, Murer H (1993) Localization of $\mathrm{NaPi}-1$, a Na/Pi cotransporter, in rabbit kidney proximal tubules. II. Localization by immunohistochemistry. Pflugers Arch 424: 210-215

Chong SS, Kristjansson K, Zoghbi HY, Hughes MR (1993) Molecular cloning of the cDNA encoding a human renal sodium phosphate transport protein and its assignment to chromosome 6p21.3-p23. Genomics 18: 355-359

Lauer P, Meyer NC, Prass CE, Starnes SM, Wolff RK, Gnirke A (1997) Clone-contig and STS maps of the hereditary hemochromatosis region on human chromosome 6p21.3-22. Genome Res 7: 457-470

Maruyama K, Sugano S (1994) Oligo-capping: a simple method to replace the cap structure of eukaryotic mRNAs with oligo-ribonucleotides. Gene 138: 171-174

Murer H, Werner A, Reshkin S, Wuarin F, Biber J (1991) Cellular mechanisms in proximal tubular reabsorption of inorganic phosphate. Am. J Physiol 260: C885-899

Murer H, Markovich D, Biber J (1994) Renal and small intestinal sodiumdependent symporters of phosphate and sulphate. J Exp Biol 196: 167-181

Saito T, Seki N, Ishii H, Ohira M, Hayashi A, Kozuma S, Hori T (1997) Complementary DNA cloning and chromosomal mapping of a novel phosphatidylinositol kinase gene. DNA Res 4: 301-305

Suzuki Y, Yoshitomo-Nakagawa K, Maruyama K, Suyama A, Sugano S (1997) Construction and characterization of a full length and 5'end-enriched cDNA library. Gene 200: 149-156 